\title{
Perbedaan Perilaku Pemenuhan Kebutuhan Spiritual Berdasarkan Tingkat Pengetahuan dan Sikap Pasien Rawat Inap Di Rumah Sakit Raden Mattaher Jambi
}

\author{
Faridah* \\ Program Studi D III Fisioterapi STIKes Baiturrahim Jambi \\ *Correspondence email: taherfaridah821@gmail.com
}

\begin{abstract}
Abstrak. Kebutuhan spiritual sangat penting selama periode sakit, karena ketika sakit, energi seseorang akan berkurang dan spiritual orang tersebut akan terpengaruh, oleh karena itu kebutuhan spiritual pasien perlu dipenuhi. Penelitian ini bertujuan Untuk mengetahui perbedaan perilaku pemenuhan kebutuhan spiritual berdasarkan tingkat pengetahuan dan sikap pasien rawat Inap di Rumah Sakit Umum Raden Mattaher Jambi.Penelitian ini merupakan penelitian kuantitatif yang bersifat analitik untuk mengetahui perbedaan perilaku pemenuhan kebutuhan spiritual berdasarkan tingkat pengetahuan dan sikap pasien rawat Inap di Rumah Sakit Umum Raden Mattaher Jambi. Sampel penelitian adalah pasien rawat Inap di ruang Bedah. Interne dan Paru dengan lama perawatan lebih dari 1 minggu. Hasil penelitian menunjukkan bahwa Analisis Chi Square menunjukkan nilai $p$-value $=$ $0,001<0,05$ berarti terdapat perbedaan pemenuhan kebutuhan spiritual berdasarkan sikap pasien dan nilai $p$-value $=0,036<0,05$ yang berarti juga terdapat perbedaan Pemenuhan kebutuhan Spiritual berdasarkan tingkat pengetahuan pasien rawat Inap di RSUD Raden Mattaher jambi. Pasien memiliki sikap yang baik dan pengetahuan yang tinggi maka pemenuhan kebutuhan spiritualnya akan baik pula. Harapan hasil penelitian ini dapat digunakan oleh masyarakat dan khususnya tenaga kesehatan untuk memperhatikan pasien bukan hanya kebutuhan bio, psiko, social saja, namun pemenuhan kebutuahn spiritual pasien perlu diperhatikan agar asuhan keperawatn dapat dilaksanakan secara komprehensif
\end{abstract}

Kata Kunci: Pengetahuan; Pemenuhan Kebutuhan Spiritual; Sikap Pasien

\begin{abstract}
Spiritual needs are very important during the sick period, because when sick, one's energy will decrease and that person's spirituality will be affected, therefore the patient's spiritual needs need to be met. This study aims to determine differences in the behavior of fulfilling spiritual needs based on the level of knowledge and attitudes of inpatients at the Raden Mattaher General Hospital, Jambi. This research is a quantitative analytic study to determine differences in behavior to fulfill spiritual needs based on the level of knowledge and attitudes of inpatients at Raden Mattaher General Hospital Jambi. The research sample was inpatients in the Surgery room. Interne and, Lungs with a treatment duration of more than 1 week. The results showed that the Chi Square analysis showed p-value $=0.001<0.05$, which means that there are differences in the fulfillment of spiritual needs based on patient attitudes and the p-value $=0.036<0.05$, which means that there are also differences in fulfilling spiritual needs based on the patient's level of knowledge. Hospitalization at Raden Mattaher Hospital, Jambi. The patient has a good attitude and high knowledge, so his spiritual needs will be fulfilled as well. It is hoped that the results of this research can be used by the community and especially health workers to pay attention to patients, not only bio, psycho, social needs, but the fulfillment of patients' spiritual needs needs to be considered so that nursing care can be carried out comprehensively.
\end{abstract}

Keywords: Knowledge; Spiritual Need Fulfillment; Patient Attitudes

\section{PENDAHULUAN}

Manusia sebagai mahluk holistik yang terdiri dari unsur biologis, psikologis, sosial dan spiritual yang merupakan perpaduan aspek jasmani dan rohani dengan kebutuhan yang berbeda-beda sesuai dengan tingkat perkembangannya (Hidayat, 2016). Unsur-unsur tersebut merupakan suatu sistem yang saling berhubungan, keterkaitan satu sama lainnya, jika salah satu unsur itu bermasalah maka unsur yang lainpun akan memberikan dampak.

Manusia memiliki unsur fisiologis biologis terdiri dari gabungan sistem organ tubuh yang menjalani kehidupan dan perkembangan, Sedangkan unsur psikologis pada manusia akan terpancar melalui kepribadian baik prilaku maupun kejiwaan sehingga unsur psikologis tersebut merupakan pengembangan dari kepribadian setiap manusia.Unsur lain yang tidak bisa diabaikan adalah unsur spiritual yang menyangkut keyakinan atau kepercayaan individu tentang adanya yang menciptakan sehingga manusia dapat menyadari pentingnya arti spiritual dalam kehidupan agar bermanfaar di dunia maupun diakherat.

Menurut Kamus Besar Bahasa Indonesia (2018) spiritual adalah yang berhubungan denga sifat kejiwaan (rohani dan batin). Spiritual merupakan faktor penting yang membantu individu mencapai keseimbanagn yang diperlukan untuk memelihara kesehatan dan kesejahteraan serta beradaptasi dengan penyakit (Potter \& Perry, 2010). Hakekat spiritual adalah seni manusia memaknai hidup tentang serangkaian usaha manusia dalam menjalani hidup, sehingga kehidupannya memiliki arti. 
Salah satu kebutuhan dasar manusia adalah membutuhkan rasa aman dan nyaman. Oleh karena itu manusia mencari cara untuk mendapatkannya dengan melakukan tindakan tertentu yang merubah persepsi atau kondisi berfikir yang menimbulkan sensasi rasa nyaman dan memiliki arti.

Sehingga dapat disimpulkan bahwa kehidupan spiritual salah satu kebutuhan dasar manusia untuk mencari tujuan hidup, memaknai hidup, mencintai dan dicintai, artinya kebutuhan spiritual dapat dimanfaatkan untuk memberikan efek proteksi diri dan penyangga dalam melawan keputusan dalam menanggapi setiap kehidupannya. Spiritual merupakan hubungan antar manusia dengan tuhan, namun setiap orang memaknai kebutuhan spiritual yang berbeda-beda

Manusia dapat mengalami stres, yang dapat mengalami perubahan dalam tubuhnya namun cara pengungkapanya berbeda-beda. Sesorang yang sedang mengalami kecemasan dan stres akibat masalah yang dihadapinya pada umumnya akan mendekatkan diri dengan Allah dengan berdo'a. Hal ini sesuai dengan penelitian Yoga et al (2019) bahwa pelatihan relaksasi dzikir efektif menurunkan stress..

Pada Kondisi sehat, masing-masing individu dapat memenuhi kebutuhan dasar berupa aktivitas yang dilakukannya sehari-hari tersebut dengan baik. Sedangkan pada kondisi sakit, pasien membutuhkan bantuan orang lain untuk memenuhi kebutuhan dasarnya. Dengan kondisi seperti ini pasien merasakan ketidakbedayaannya sehingga dapat memicu terjadinya stress.

Pasien dengan kondisi lemah, hendaknya mendekatkan diri dengan Allah SWT, karena ketika sakit pasien akan merasakan kehilanagan, duka cita atau perubahan hidup yang besar individu menggunakan sumber daya spiritual untuk membantu mereka beradaptasi atau menimbulkan kebutuhan dan masalah spiritual (Potter \& Perry, 2010).

Manusia tidak luput dari ujian, salah satunya penyakit. Orang yang sakit, apalagi sakit parah, akan mengalami kegalauan dan kegundahan yang tidak bisa dielakkan. Berbeda dengan orang yang memiliki makna hidup yang sangat dalam, walaupun mengidap penyakit yang berbahaya, orang tersebut masih bisa berpikir jernih. Tidak ada yang sia-sia di dunia seandainya dapat mengambil sisi positifnya, semua itu memang harus terjadi dan harus dihadapi.

Spiritual merupakan bagian yang tidak terlepaskan dari kualitas hidup. Spiritualitas dianggap konsep yang lebih luas dan inklusif dari agama meskipun hubungan konsep tersebut cukup kompleks. Ada perbedaan antara spiritual dan religius, Spiritual merupakan kesadaran setiap individu tentang, asal, tujuan dan nasib, sedangkan agama adalah praktek perilaku tertentu yang dihubungkan dengan kepercayaan yang dinyatakan oleh institusi tertentu yang dianut oleh setiap anggotanya. Agama memiliki kesaksian iman, komunitas dan kode etik. Seseorang bisa menganut agama yang sama, namun belum tentu mereka memiliki jalan atau tingkat spiritual yang sama (Hamid, 2009)

Perawat sebagai tenaga kesehatan profesional mempunyai kesempatan yang paling besar untuk memberikan pelayanan kesehatan khususnya pelayanan/asuhan keperawatan yang komprehensif dengan membantu pasien memenuhi kebutuhan dasarnya. Asuhan keperawatan yang diberikan oleh perawat tidak bisa lepas dari aspek spiritual saja, perawat hendaknya berupaya membantu memenuhi kebutuhan spiritual pasien dengan memfasilitasi pemenuhan kebutuhan spiritual pasien tersebut. Walaupun keyakinan spiritual dan keagamaan perawat dan pasien yang dimiliki tidak sama. Hasil evaluasi Roby Gultom et al, (2020) tentang peranan faktor spiritualitas perawat dudalam mendukung aspek spiritualpasien rawat inap menunjukkan bahwa sudah terpenuhi kebutuhan spiritualnya oleh perawat yang menerapkan aspek spiritualnya dengan baik.

Teori ilmu keperawatan Neuman memandang manusia secara holistik meliputi faktor biologis, psikologis, sosial, budaya, faktor perkembangan dan faktor spiritual yang saling berhubungan satu sama lainnya secara dinamis dan tidak dapat dipisahkan yaitu faktor fisiologis meliputi, struktur dan fungsi tubuh, faktor psikologis terdiri dari proses dan hubungan mental, faktor sosial budaya meliputi fungsi sistem yang menghubungkan sosial, ekspektasi kultural dan aktivasi, faktor perkembangan sepanjang hidup dan faktor spiritual pengaruh kepercayaan spiritual (Tomey \& Alligood, 2006)

Pasien yang berada diruang perawatan jika tidak terpenuhinya kebutuhan spiritualnya akan mengalami distress spriritual yang akan menimbulkan keputusasaan dimana pasien sudah tidak lagi percaya pada Tuhan, tidak lagi melakukan ibadah dan hilang pengharapan pada Tuhan (Sriyono, 2019)

Data dari register pasien didapatkan lima penyakit kronis yang ditemui yaitu hipertensi, stroke, gagal ginjal, hepatitis, dan kanker. Berdasarkan wawancara dengan pasien rawat inap di Rumah Sakit Umum Raden Mattaher Ketika melakukan tanya jawab seputar keyakinan pasien terlihat ekspresi pasien ketidaknyamanan, kecemasan, sedih, ketakutan, kesepian yang bisa menghambat kesehatan pasien secara fisik, psikologis dan spiritual. dan pada umumnya pasien dalam menyikapi penyakitnya adalah dengan berdo'a ,sedangkan yang melakukan sholat jarang sekali bahkan pasien menerima pasrah kondisi penyakitnya tanpa berdo'a.

\section{METODE}

Penelitian ini merupakan penelitian kuantitatif yang bersifat analitik untuk mengetahui perbedaan perilaku pemenuhan kebutuahn berdasarkan tingkat pengetahuan dan sikap. Populasi dalam penelitian ini 
adalah pasien rawat inap di ruang bedah, paru interne berjumlah 105, Sampel pada penelitian ini diambil dari jumlah populasi yang tersedia yaitu sebanyak 44 dengan rincian pasien di ruang bedah 18 orang, ruang paru 3 orang, ruang interne 23 dengan menggunakan tehnik purposive sampling dengan kriteria inklusinya yaitu Pasien rawat inap lebih dari 1 minggu Bisa diajak berkomunikasi. Penelitian dilakukan pada bulan November s/d Desember 2018 di Rumah Sakit Umum Raden Mattaher Jambi. Tehnik pengumpulan data menggunakan data primer dengan menggunakan kuisioner

Analisis data dilakukan secara univariat untuk mengetahui gambaran perilaku pemberian pemenuhan kebutuhan spiritual, pengetahuan dan sikap ibu di RSUD Raden Mattaher Jambi. Selain itu juga menggunakan analisis bivariat digunakan untuk mencari perbedaan antara variabel dependen dan variabel independen melalui uji statistik. Uji statistik yang digunakan ialah uji chi square. Untuk melihat batas bermakna $\alpha 0,05$.

\section{HASIL DAN PEMBAHASAN}

Tabel 1. Karakteristik Responden

\begin{tabular}{llll}
\hline No & Karakteristik Responden & (n) & $\%$ \\
\hline 1 & Umur Pasien & & \\
& $<30$ tahun & 4 & 9.10 \\
& 30-45 tahun & 13 & 29.54 \\
& $>45$ tahun & 27 & 61.36 \\
2 & Pendidikan & & \\
& SD & 2 & 3.3 \\
& SMP & 6 & 13.6 \\
& SMA & 33 & 75,0 \\
& Perguruan Tinggi & 3 & 6.8 \\
& Pekerjaan & & 50 \\
& Buruh/Tani & 22 & 23 \\
& Swasta & 10 & 27 \\
& PNS & 12 &
\end{tabular}

Sumber: Olahan Data, 2018

Tabel 2. Pengetahuan Responden tentang pemenuhan Kebutuhan Spiritual

\begin{tabular}{|c|c|c|c|c|c|}
\hline & \multirow{3}{*}{ Pernyataan } & \multicolumn{4}{|c|}{ Jumlah responden berdasarkan jawaban } \\
\hline & & \multicolumn{2}{|c|}{ Benar } & \multicolumn{2}{|c|}{ Salah } \\
\hline & & org & $\%$ & org & $\%$ \\
\hline 1 & Defenisi Spiritual & 32 & 72,7 & 12 & 27,3 \\
\hline 2 & Fungsi Pemenuhan Kebutuhan spiritual & 29 & 65,9 & 15 & 34,1 \\
\hline 3 & Pelaksanaan kebutuhan spiritual & 21 & 47,7 & 23 & 52,3 \\
\hline 4 & Harmonisasi kebutuhan spiritual & 12 & 27,3 & 32 & 72,7 \\
\hline 5 & Pentingnya kekuatan spiritual & 37 & 84,1 & 7 & 15,9 \\
\hline 6 & Komponen Kebutuhan dasar spiritual & 20 & 45,5 & 24 & 54,5 \\
\hline 7 & Faktor yang mempengaruhi kebutuhan spiritual & 36 & 81,8 & 8 & 18,2 \\
\hline 8 & Konsep Kesehatan Spiritual & 43 & 97,7 & 1 & 2,3 \\
\hline 9 & Kriteria tercapainya kebutuhan spiritual & 23 & 52,3 & 21 & 47,7 \\
\hline 10 & Indikasi spiritual & 39 & 88,6 & 5 & 11,4 \\
\hline 11 & Spiritual berhubungan dengan Tuhan TME & 35 & 79,5 & 9 & 20,5 \\
\hline 12 & Hubungan spritual dengan individu & 34 & 77,3 & 10 & 22,7 \\
\hline 13 & Karakteristik Spiritual & 36 & 81,8 & 8 & 18,2 \\
\hline 14 & Pentinya Spiritual & 29 & 65,9 & 15 & 34,1 \\
\hline 15 & Fungsi Spiritual bagi Kehidupan & 37 & 84,1 & 7 & 15,9 \\
\hline 16 & Pernyataan tentang pentingnya spiritual & 20 & 45,5 & 24 & 54,5 \\
\hline 17 & Pernyataan tentang defenisi spiritual & 36 & 81,8 & 8 & 18,2 \\
\hline 18 & Pernyataan tentang dimensi spiritual & 43 & 97,7 & 1 & 2,3 \\
\hline 19 & Pernyataan yang benar tentang pemenuhan Spiritual & 40 & 90,9 & 4 & 9,1 \\
\hline 20 & Menurut Bapak/Ibu apa makna dan tujuan hidup & 43 & 97,7 & 1 & 2,3 \\
\hline
\end{tabular}

Berdasarkan jawaban responden terdapat pernyataan yang paling banyak dijawab adalah pernyataan tentang konsep kesehatan spiritual, dimensi spiritual dan makna hidup yaitu sebanyak 43 orang $(97,7 \%)$

Menurut Kamus Besar Bahasa Indonesia (2018), spiritual artinya adalah yang berhubungan dengan sifat kejiwaan (rohani dan batin). Spiritual merupakan kebangkitan atau pencerahan dalam diri untuk mencapai tujuan dan makna dalam hidup serta bagian paling pokok dari masalah kesehatan dan kesejahteraan seseorang. Dimensi spiritualitas ada 3 macam yaitu tanggung jawab, pemaaf, dan pengasih jika dimensi spiritual itu ada dalam diri seseorang maka akan tertimbul rasa kedamaian dan kebahagiaan (Ginanjar, 2004)

Kebutuhan spiritual merupakan kebutuhan dasar manusia. Apabila seseorang dalam keadaaan sakit, maka hubungan dengan Tuhannya pun semakin dekat, mengingat seseorang dalam kondisi sakit menjadi lemah dalam segala hal, pada umumnya manusia beranggapan tidak ada yang mampu menyambuhkan penyait kesembuhan, kecuali Sang Kholiq.

Perawat sebagai tenaga kesehatan yang paling banyak kontak dengan pasien memiliki kewajiban untuk 
membantu terpenuhinya kebutuhan dasar pasien, khususnya kebutuhan spiritual pasien disamping memenuhi kebutuhan dasar pasien

Salah satu bentuk pendampingan spiritual adalah dengan memberikan dukungan spiritual (Gluck, 2011). Menurut Sriyono, (2019) Keperawatan spiritual tidak hanya terbatas pada ritual kepribadian saja namun perlu juga intervesi sedehana seperti komunikasi terbuka, membantu pasien untuk berdo'a danberkolaborasi denga keluarga dan pemimpin agama dapat diimplementasikan dalam perawatan kepada pasien.

Badan Kesehatan Dunia (WHO) telah mendefinisikan manusia sebagai makhluk psikologis, sosial, dan spiritual. Sementara tak sedikit psikolog yang percaya bahwa kecerdasan spiritual adalah faktor yang berperan penting bagi kesehatan mental seseorang.

Kecerdasan spiritual adalah jenis kecerdasan yang erat kaitannya dengan kemampuan spiritual yang membantu seseorang untuk hidup lebih baik. Memiliki kemampuan ini memungkinkan individu untuk menyatukan spiritualitas, kehidupan batin (inner life), dan kehidupan di luar dirinya (oute life). Membangun kecerdasan spiritual dapat dilakukan dengan cara: melatih kesadaran, meditasi, melakukan visualisasi, berkumpul dengan komunitas dan mendekatkan diri dengan alam

Tabel 3. Sikap Responden terhadap Pemenuhan Kebutuhan Spiritual

\begin{tabular}{|c|c|c|c|c|c|c|c|c|c|}
\hline \multirow{3}{*}{ No. } & \multirow{3}{*}{ Pernyataan } & \multicolumn{8}{|c|}{ Jumlah responden berdasarkan jawaban } \\
\hline & & \multicolumn{2}{|c|}{ SS } & \multicolumn{2}{|c|}{$\mathrm{S}$} & \multicolumn{2}{|c|}{ TS } & \multicolumn{2}{|c|}{ STS } \\
\hline & & org & $\%$ & org & $\%$ & org & $\%$ & org & $\%$ \\
\hline 1 & Keyakinan dan makna Hidup & 18 & 40,9 & 26 & 59,1 & 0 & 0 & 0 & 0 \\
\hline 2 & Peran Keluarga dalam pemenuhan kebutuhan spiritual & 13 & 29,5 & 29 & 65,9 & 2 & 4,5 & 0 & 0 \\
\hline 3 & Ritual Ibadah yang dilakukan responden & 7 & 15,9 & 35 & 79,5 & 2 & 4,5 & 0 & 0 \\
\hline 4 & Apakan responden melakukan ritual ibadah & 11 & 25,0 & 33 & 75,0 & 0 & 0 & 0 & 0 \\
\hline 5 & Infomasi tentang keagamaan & 11 & 25,0 & 33 & 75,0 & 0 & 0 & 0 & 0 \\
\hline 6 & Apakah Responden terlibat dalam keagamaan & 28 & 63,6 & 12 & 27,3 & 4 & 9,1 & 0 & 0 \\
\hline 7 & Apakah masalah membuar responden berubah dalam menjalani hidup & 3 & 6,8 & 32 & 72,7 & 9 & 20,5 & 0 & 0 \\
\hline 8 & Keluarga memberikan dukungan misalnya memberikan uang & 0 & 0 & 31 & 70,5 & 11 & 25,0 & 2 & 4,5 \\
\hline 9 & Apakah responden bersilaturrahmi ke rumah keluarga & 3 & 6,8 & 31 & 70,5 & 8 & 18,2 & 2 & 4,5 \\
\hline 10 & Apakah responden rutin melakukan ibadah & 6 & 13,6 & 27 & 61,4 & 11 & 25,0 & 0 & 0 \\
\hline 11 & Apakah responden mempunyai masalah & 11 & 25,0 & 33 & 75,0 & 0 & 0 & 0 & 0 \\
\hline 12 & Bagaimana pandangan responden dalam beragama & 14 & 31,8 & 28 & 63,6 & 2 & 4,5 & 0 & 0 \\
\hline 13 & Apakah responden menceritakan jika ada masalah & 8 & 18,2 & 34 & 77,3 & 2 & 4,5 & 0 & 0 \\
\hline 14 & Apakah pekerjaan responden mengganggu ibadah & 6 & 13,6 & 27 & 61,4 & 9 & 20,5 & 0 & 0 \\
\hline 15 & Apakah jika responden sakit mengganggu dalam beribadah & 8 & 18,2 & 36 & 81,8 & 0 & 0 & 0 & 0 \\
\hline 16 & Jika sakit apakah ibadah semakin meningkat & 0 & 0 & 39 & 88,6 & 5 & 11,4 & 0 & 0 \\
\hline 17 & Jika sakit apakah menurunkan iman responden & 2 & 4,5 & 41 & 93,2 & 1 & 2,3 & 0 & 0 \\
\hline 18 & Jika sakit apakah membutuhkan kegiatan spiritual & 1 & 2,3 & 38 & 86,4 & 4 & 9,1 & 0 & 0 \\
\hline 19 & Apakah responden membutuhkan kegiatan spiritual & 4 & 9,1 & 39 & 88,6 & 0 & 0 & 1 & 2,3 \\
\hline 20 & Apakah ada peristiwa yang membuat hidup berubah & 10 & 22,7 & 30 & 68,2 & 4 & 9,1 & 0 & 0 \\
\hline
\end{tabular}

Sumber: Olahan Data, 2018

Berdasarkan jawaban yang diberikan terdapat pernyataan responden terlibat dalam keagamaan yang menjawab sangat setuju $53,6 \%$, pada pernyataan Jika sakit apakah menurunkan iman responden dijawab setuju sebanyak 93,2\% Keluarga memberikan dukungan misalnya memberikan uang dan apakah responden rutin melakukan ibadah dijawab tidak setuju 25\%

Iman secara etimologis berarti "kepercayaan atau pembenaran", yakni sikap membenarkan sesuatu, atau menganggap dan mempercayai sesuatu yang benar. Sedangkan dalam perspektif psikologis, dimensi batin dari iman merupakan aspek iman yang berkaitan dengan keadaan dan perbuatan kejiwaan seseorang baik pada ranah kognisi (pikiran), afeksi (perasaan atau emosi), dan konasi (kehendak). Dimensi ini berkaitan dengan keyakinan dan sikap batin seseorang. Sedangkan dimensi lahir dari iman berkaitan dengan tindakan dan perbuatan lahir yang didorong dan digerakkan oleh keyakinan dan sikap batin, baik kegiatan yang berkaitan dengan praktek ritual agama (ibadah) maupun kegiatan sosial kemasyarakatan. Pandangan dan konstruksi teoritik iman seperti tersebut di atas selaras dengan pandangan Zakiah Daradjat (1990) menyatakan bahwa: Keimanan adalah suatu proses kejiwaan yang tercakup di dalamnya semua fungsi jiwa, perasaan dan pikiran sama-sama meyakinkannya.Keimanan adalah proses kejiwaan yang melibatkan fungsi kognisi dan afeksi secara bersama. Keimanan yang sesungguhnya harus ada realisasinya dalam segala sikap dan tindakan. Orang yang benarbenar beriman akan merasa ridha dan ikhlas, tidak merasa kesepian, resah dan cemas, hatinya tenteram dan bahagia.

Pasien yang menjalani perawatan di Rumah Sakit pada umumnya menderita penyakit kronis Kondisi ini berdampak secara psikologis, sosial, dan spiritual. Seringkali kondisi tersebut menimbulkan ketidak berdayaan dan keputusasaan pada pasien dan pada akhirnya jatuh dalam kondisi distres spiritual dimana 
pasien sudah tidak lagi percaya pada Tuhan, tidak lagi melakukan ibadah, dan hilang pengharapan terhadap Tuhan. Proses penyembuhan dan mekanisme koping tentunya akan terhambat jika pasien mengalami distres spiritual bahkan adanya pasien mengalami depresi .

Manusia diciptakan sebagai makhluk yang paling sempurna. Tidak hanya berupa fisik, namun juga dilengkapi oleh komponen biologis, psikologis, sosial, dan spiritual. Komponen-komponen tersebut menuntut untuk selalu dipenuhi kebutuhannya. Jika pada saat kondisi sehat, kebutuhan-kebutuhan tersebut dapat dipenuhi, namun jika seseorang dalam kondisi sakit yang memiliki penyakit yang serius hendaknya perawat sebagai tenaga kesehatan yang paling lama berada di dekat pasien untuk membantu terpenuhinya kebutuhan dasar pasien, khususnya kebutuhan spiritual disamping memenuhi kebutuhan dasar yang lain. Pada beberapa penelitian disebutkan bahwa peran perawat dalam pemenuhan kebutuhan spiritual masih belum optimal. Perawat di ruang rawat intensif lebih banyak menekankan pada kebutuhan fisik saja, seperti menstabilkan tanda vital pasien dan mengatasi nyeri, namun mereka jarang memberikan perhatian pada kebutuhan spiritual. Asuhan keperawatan spiritual telah banyak dibahas dan diteliti. Namun pada praktiknya perawat kesulitan untuk menerapkannya kepada pasien khususnya pasien dengan perawatan intensif, walaupun dalam kondisi terintubasi, tidak sadar, dan tidak berdaya, pasien tetaplah manusia yang memiliki rasa dan harus tetap diperlakukan dengan baik. Telaah sistematis yang telah dilakukan menemukan bahwa pemenuhan kebutuhan spiritual tidak hanya terbatas pada ritual peribadatan saja. Komunikasi adalah komponen yang penting untuk dilakukan. Intervensi sederhana seperti komunikasi bersama pasien, mendengarkan keluh kesah pasien, dan melakukan tanya jawab seputar keyakinan pasien dapat dilakukan. Bersama dengan pasien, perawat dapat mengetahui pasien dalam mengekspresikan pengalaman rasa sakit, ketidaknyamanan, dan mendengarkan ekspresi emosi dan kecemasan, seperti depresi, kesedihan, ketakutan atau kesepian, yang bisa menghambat kesehatan mereka secara fisik, emosional dan spiritual.

Perawat juga dapat memfasilitasi pasien untuk melakukan doa atau membacakan kitab. Doa adalah metode utama dimana pasien dapat berhubungan dengan kondisi spiritualnya. Doa memiliki efek positif pada psikologis dan kesejahteraan fisik. Identifikasi kebaikan pasien, menghormati, berbicara dan mendengarkan, dan berdoa adalah aspek-aspek penting dari perawatan spiritual pasien. Berdoa bersama atau berdoa untuk pasien, menghabiskan waktu bersama pasien dan meyakinkan pasien, mendengarkan pasien secara verbal tentang ketakutan dan kecemasan mereka, menunjukkan rasa hormat terhadap martabat dan keyakinan spiritual agama mereka, menunjukkan kebaikan dan peduli, mengatur kunjungan pemimpin spiritual/agama dan menawarkan harapan adalah hal-hal yang penting dan sederhana yang dapat dilakukan untuk pasien. Perawat juga dapat melakukan kolaborasi dengan pemuka agama dan keluarga untuk melakukan pembimbingan kepada pasien dan memnuhi kebutuhan spiritual pasien. Keluarga memiliki peran penting dalam mendukung dan meningkatkan kondisi kesehatan pasien.

Keperawatan spritual tidak hanya terbatas pada ritual peribadatan saja. Intervensi sederhana seperti komunikasi terbuka, membantu pasien untuk berdoa dan berkolaborasi dengan keluarga dan pemimpin agama dapat diimplementasikan dalam perawatan kepada pasien untuk memenuhi kebutuhan spiritual mereka khususnya pasien yang dilakukan perawatan intensif. Dengan demikian, perawat dapat dengan mudah untuk melakukan intervensi keperawatan spiritual sehingga pasien tidak mengalami distres spiritual, memiliki motivasi dan keyakinan untuk sembuh atau meningkatkan

Kondisi kesehatannya. Perawatan spiritual juga dapat membuat pasien menerima kondisinya, merasa nyaman, dan dapat menjadi fasilitas untuk mengantarkan pasien pada kematian yang damai.

Tabel 4. Perilaku Responden terhadap Pemenuhan Kebutuhan Spiritual

\begin{tabular}{|c|c|c|c|c|c|c|c|c|c|}
\hline \multirow{3}{*}{ No } & \multirow{3}{*}{ Pernyataan } & \multicolumn{8}{|c|}{ Jumlah responden berdasarkan jawaban } \\
\hline & & \multicolumn{2}{|c|}{ Selalu } & \multicolumn{2}{|c|}{ Sering } & \multicolumn{2}{|c|}{$\begin{array}{c}\text { Kadang- } \\
\text { kadang }\end{array}$} & \multicolumn{2}{|c|}{$\begin{array}{l}\text { Tidak } \\
\text { Pernah }\end{array}$} \\
\hline & & org & $\%$ & org & $\%$ & org & $\%$ & org & $\%$ \\
\hline 1 & $\begin{array}{l}\text { Sangat merasa terpenuhi dan puas dengan kehidupan yang dijalani saat } \\
\text { ini }\end{array}$ & 15 & 34,1 & 29 & 65,9 & 0 & 0 & 0 & 0 \\
\hline 2 & Saya berfikir bahwa hidup ini memiliki makna yang kurang berarti & 15 & 34,1 & 29 & 65,9 & 0 & 0 & 0 & 0 \\
\hline 3 & Saya merasa menjadi manusia yang baik tentang arah hidup saya & 14 & 31,8 & 30 & 68,2 & 0 & 0 & 0 & 0 \\
\hline 4 & Saya merasa kurang menikmati hidup & 15 & 34,1 & 29 & 65,9 & 0 & 0 & 0 & 0 \\
\hline 5 & Saya merasa lebih mantap memandang masa depan saya & 13 & 29,5 & 31 & 70,5 & 0 & 0 & 0 & 0 \\
\hline 6 & Saya merasakan bahwa hidup sebagai pengalaman yang positif/baik & 16 & 36,4 & 28 & 63,6 & 0 & 0 & 0 & 0 \\
\hline 7 & Saya merasa bingung ketika saya mencoba memahami kehidupan saya & 14 & 31,8 & 30 & 68,2 & 0 & 0 & 0 & 0 \\
\hline 8 & Saya memliliki gambaran hidup yang lebih baik tentang masa depan & 10 & 22,7 & 34 & 77,3 & 0 & 0 & 0 & 0 \\
\hline 9 & $\begin{array}{l}\text { Saya tidak tahu siapa saya dari mana saya berasal kemana saya akan } \\
\text { pergi }\end{array}$ & 13 & 29,5 & 31 & 70,5 & 0 & 0 & 0 & 0 \\
\hline 10 & Saya merasa memiliki tujuan hidup yang baru dan lebih berharga & 14 & 31,8 & 30 & 68,2 & 0 & 0 & 0 & 0 \\
\hline
\end{tabular}




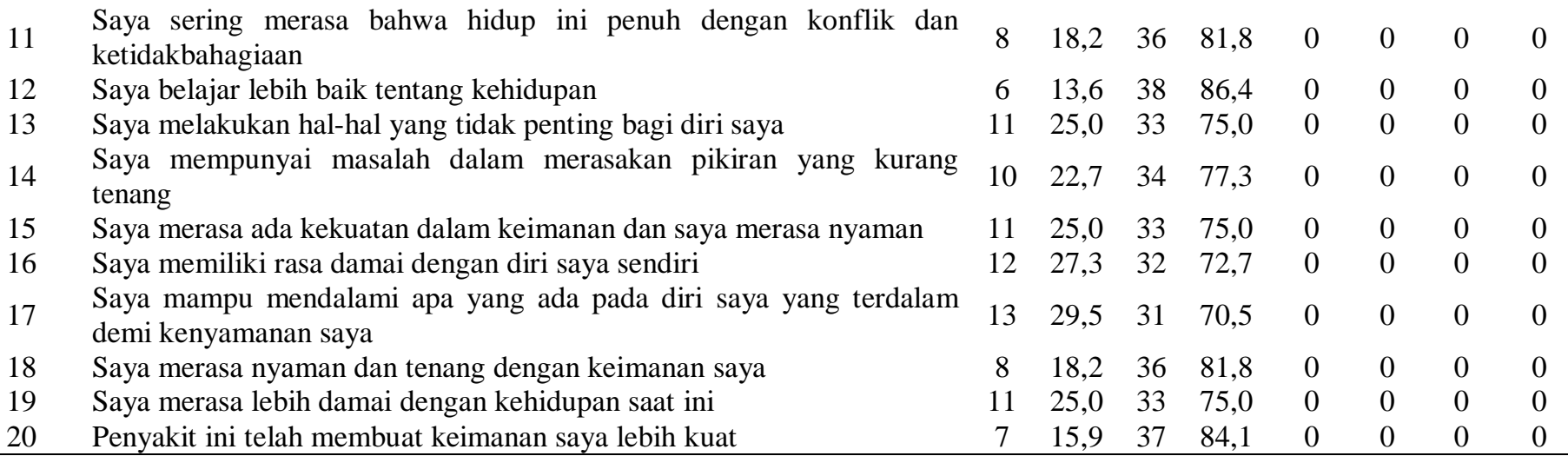

Sumber: Olahan Data, 2018

Berdasarkan jawaban yang diberikan terdapat pernyataan Saya merasakan bahwa hidup sebagai pengalaman yang positif/baik dijawab selalu $(36,4 \%)$ dan Saya belajar lebih baik tentang kehidupan dijawab sering $(86,4 \%)$

Perilaku merupakan seperangkat perbuatan atau tindakan seseorang dalam melalukan respon terhadap sesuatu dan kemudian dijadikan kebiasaan karena adanya nilai yang diyakini.

Perilaku manusia pada hakekatnya adalah tindakan atau aktivitas dari manusia baik yang diamati maupun tidak dapat diamati oleh interaksi manusia dengan lingungannya yang terwujud dalam bentuk pengetahuan, sikap, dan tindakan. Perilaku secara lebih rasional dapat diartikan sebagai respon organisme atau seseorang terhadap rangsangan dari luar subyek tersebut. Respon ini terbentuk dua macam yakni bentuk pasif dan bentuk aktif dimana bentuk pasif adalah respon internal yaitu yang terjadi dalam diri manusia dan tidak secara langsung dapat dilihat dari orang lain sedangkan bentuk aktif yaitu apabila perilaku itu dapat diobservasi secara langsung (Triwibowo, 2015). Artinya seseorang cendrungan berperilaku tertentu sesuai dengan sikap yang dimilikinya.
Sikap (attitude) adalah kumpulan komponen kognitif, afektif, dan konatif yang saling berinteraksi dalam memahami, merasakan, dan berperilaku terhadap suatu objek. Yang disebut triparte model yang dikemukakan oleh Rosenberg dan Hovland (Azwar, 2011). Ketiga komponen afeksi, kognisi dan konasi sebagai faktor jenjang pertama dalam suatu model hirarkis. Ketiganya didefinisikan tersendiri dan kemudian dalam abtraksi yang lebih tinggi membentuk konsep sikap.

Menurut sebagian psikolog, perilaku manusia berasal dari motivasi atau dorongan yang ada dalam diri manusia dan motivasi itu merupakan salah satu usaha untuk memenuhi kebutuhan yang ada dalam diri manusia.

Dari uraian diatas dapat dipahami bahwa motivasi berkaitan erat dengan perilaku. Banyak teori tentang motivasi yang banyak digunakan sampai saat ini. Salah satunya adalah adalah teori dari Abraham Maslow tentang Hirarki Kebutuhan. Dalam teori ini dijelaskan bahwa manusia termotivasi untuk memenuhi kebutuhankebutuhan hidupnya. Kebutuhan-kebutuhan tersebut memiliki tingkatan atau hirarki, mulai dari yang bersifat dasar (fisiologis) sampai yang paling tinggi (aktualisasi diri).

Tabel 5. Perbedaan Pemenuhan kebutuhan Spiritual Berdasarkan Tingkat Pengetahuan Pasien Rawat Inap di RSUD Raden Mattaher Jambi

\begin{tabular}{|c|c|c|c|c|c|c|c|c|}
\hline \multirow{3}{*}{ No } & \multirow{3}{*}{ Pengetahuan } & \multicolumn{4}{|c|}{ Pemenuhan Kebutuhan Spiritual } & \multirow{2}{*}{\multicolumn{2}{|c|}{ Jumlah }} & \multirow{2}{*}{$p$-value } \\
\hline & & \multicolumn{2}{|c|}{ Baik } & \multicolumn{2}{|c|}{ Kurang Baik } & & & \\
\hline & & Jumlah & $\%$ & Jumlah & $\%$ & Jumlah & $\%$ & \multirow{4}{*}{0,036} \\
\hline 1 & Tinggi & 18 & 66,7 & 5 & 29,4 & 23 & 52,3 & \\
\hline 2 & Rendah & 9 & 33,3 & 12 & 70,6 & 21 & 47,7 & \\
\hline \multicolumn{2}{|c|}{ Total } & 27 & 100 & 17 & 100 & 44 & 100 & \\
\hline
\end{tabular}

Sumber: Olahan Data 2018

Tabel 5. menunjukkan bahwa pasien yang memiliki pengetahuan rendah lebih banyak kurang baik yaitu 70,6\% dalam pemenuhan kebutuhan spiritual, sebaliknya pasien yang memiliki pengetahuan tinggi, lebih banyak baik yaitu $66,7 \%$ yang dalam pemenuhan kebutuhan spiritual. Artinya Pasien yang memiliki pengetahuan tinggi lmakan akan lebih baik pula dalam pemenuhan kebutuhan spiritualnya

Analisis Chi Square menunjukkan nilai $p$-value $=$ $0,036<0,05$ yang berarti terdapat perbedaan Pemenuhan kebutuhan Spiritual berdasarkan tingkat pengetahuan pasien rawat Inap di RSUD Raden Mattaher jambi 
Menurut Wawan (2010), faktor-faktor yang mempengaruhi pengetahuan adalah faktor Internal yang terdiri dari pendidikan, pengalaman, informasi dan umur. Faktor kedua adalah faktor eksternal yang terdiri dari faktor lingkungan dan sosial budaya.

Berdasarkan hasil analisis didapat bahwa terdapat pasien yang memiliki pengetahuan tinggi namun memiliki perilaku yang kurang baik hal ini menunjukkan bahwa pengetahuan yang dimiliki tidak digunakan pasien untuk pemenuhan kebutuhan spiritualnya sedangkan masih terdapat pasien yang memiliki pengetahuan rendah namun memiliki perilaku kurang baik hal ini menunjukkan bahwa perilaku responden tidak dipengaruhi oleh pengetahuannya bisa saja dipengaruhi oleh faktor lain seperti keluarga maupun petugas kesehatan.

Maka dari itu, pengetahuan pasien sangat mempengaruhi perilakunya dalam pemenuhan kebutuhan spiritual sehingga untuk meningkatkan pemenuhan kebutuhan spiritual maka dibutuhkan peran tenaga kesehatan untuk selalu meningkatkan pengetahuan masyarakat khususnya bagi pasien mengenai pentingnya pemenuhan kebutuhan spiritual melalui penyuluhan atau konseling di Ruang rawat inap RSUD Raden mattaher Jambi.

Tabel 6. Perbedaan Pemenuhan Kebutuhan Spiritual berdasarkan Sikap Pasien Rawat Inap RSUD Raden Mattaher Jambi

\begin{tabular}{|c|c|c|c|c|c|c|c|c|}
\hline \multirow{3}{*}{ No } & \multirow{3}{*}{ Sikap } & \multicolumn{4}{|c|}{ Pemenuhan Kebutuhan Spiritual } & \multirow{2}{*}{\multicolumn{2}{|c|}{ Jumlah }} & \multirow{3}{*}{ p-value } \\
\hline & & \multicolumn{2}{|c|}{ Baik } & \multicolumn{2}{|c|}{ Kurang Baik } & & & \\
\hline & & Jumlah & $\%$ & Jumlah & $\%$ & Jumlah & $\%$ & \\
\hline 1 & Baik & 21 & 77,8 & 4 & 23,5 & 19 & 43,2 & \multirow{3}{*}{0,001} \\
\hline 2 & Kurang Baik & 6 & 22,2 & 13 & 76,5 & 25 & 56,8 & \\
\hline Total & & 27 & 100 & 17 & 100 & 44 & 100 & \\
\hline
\end{tabular}

Sumber: Olahan Data, 2018

Tabel. 6 menunjukkan bahwa responden yang memiliki sikap kurang baik dalam pemenuhan kebutuhan spiritual sebanyak $76,5 \%$, sebaliknya pasien yang memiliki sikap baik dalam pemenuhan kebutuhan spiritual yaitu 78,8\%. . Artinya jika pasien memiliki sikap yang baik maka pemenuhan kebutuhan spiritualnya akan baik pula

Analisis Chi Square menunjukkan nilai $p$-value $=$ $0,001<0,05$ yang berarti terdapat perbedaan pemenuhan kebutuhan spiritual berdasarkan tingkat sikap pasien Rawat Inap RSUD Raden Mattaher Jambi.

Menurut Notoatmodjo (2010), perilaku kesehatan dipengaruhi oleh 3 faktor yaitu faktor predisposisi yang terdiri dari pendidikan, pengetahuan, sikap, persepsi, dan sikap. Faktor pendukung seperti tersedianya sarana kesehatanakses kesehatan, prioritas \& komitmen, masyarakat \& pemerintah terhadap kesehatan. Faktor pendorong seperti keluarga, teman, pengalaman, petugas kesehatan dan guru.

Berdasarkan hasil analisis didapat bahwa terdapat pasien yang memiliki sikap baik namun memiliki perilaku yang kurang baik hal ini menunjukkan bahwa sikap yang dimiliki tidak digunakan pasien untuk memenuhi kebutuhan spiritualnya dengan baik sedangkan masih terdapat pasien yang memiliki sikap kurang baik namun memiliki perilaku kurang baik hal ini menunjukkan bahwa perilaku responden tidak dipengaruhi oleh pengetahuannya bisa saja dipengaruhi oleh faktor lain seperti keluarga maupun petugas kesehatan.

Dapat diketahui bahwa dalam hal ini sikap responden mempengaruhi perilaku responden untuk memenuhi kebutuhan spiritual. Selain sikap banyak faktor lain yang mempengaruhi perilaku seseorang tidak hanya sikap saja namun pengetahuan, sikap pasien, dukungan dari petugas kesehatan, teman dan keluarga juga sangat dibutuhkan dalam pemenuhan kebutuhan spiritual. Maka dari itu untuk meningkatkan pemenuhan keutuhan spiritual dengan baik tidak hanya dibutuhkan sikap yang baik namun dibutuhkan pengetahuan dan sikap dari dalam diri untuk memenuhi kebutuhan spiritual dengan baik dan tepat waktu. Selain itu sangat dibutuhkan peran dari tenaga kesehatan untuk terus mendorong pasien khusunya pada pasien rawat inap dengan tepat waktu. Dukungan keluarga juga dibutuhkan untuk mendukung dan membantu pasien dalam memenuhi kebutuhan spiritual dengan baik.

Selain itu untuk meningkatkan sikap pasien menjadi lebih positif sebaiknya petugas kesehatan lebih meningkatkan pengetahuan pasien dengan mengadakan penyuluhan serta melakukan demonstrasi untuk mempraktekkan cara pemenuhan kebutuhan spiritual.

\section{SIMPULAN}

Hasil penelitian memperlihatkan perilaku pasien rawat inap dalam hal pemenuhan kebutuhan spiritual mempunyai pengetahuan yang tinggi dan perilaku pasien dalam hal pemenuhan kebutuhan spiritual akan lebih baik apabila pasien tersebut mempunyai sikap yang baik.

Harapannya hasil penelitian ini dapat digunakan oleh masyarakat dan khususnya tenaga kesehatan untuk memperhatikan pasien bukan hanya kebutuhan bio, psiko, social saja, namun pemenuhan ebutuahn spiritual pasien perlu diperhatikan agar asuhan keperawatn dapat dilaksanakan secara komprehensif. 


\section{DAFTAR PUSTAKA}

Agustian, Ary, Ginanjar. 2004. ESQ Power Sebuah Inner Journey Melalui alIhsan, Jakarta: Arga.

Alligood, MR \& Tomey, A.M. (2006). Nursing Theories and their work, 7 th edn, Mosby Elsevier, St. Louis, Missouri.

Azwar, S. 2011. Sikap manusia teori dan pengukurannya. Pustaka Pelajar. Yogyakarta

Gluck, S. (2011). Should Nurses Provide Spiritual Care and Support to Patient

Gultom Roby, dkk, (2020). Evaluasi Peranan Faktpr Spiritualitas Perawat di dalam Mendukung Aspek Spiritual pasien Rawat Inap di Rumah Sakit Umelda Meda, Jurnal Ilmiah Farmasi Imenlda. 1(4)

Hamid, A.Y.S. (2009). Asuhan Keperawatan Kesehatan Jiwa Bunga Rampai. Jakarta: EGC

Hidayat, A. (2016). Holistic Vision: Integrative Approach in Guidance and Counseling Services. GUIDENA: Jurnal Ilmu Pendidikan, Psikologi, Bimbingan Dan Konseling, 6(1), 1-10

KBBI, 2018. Kamus Besar Bahasa Indonesia (KBBI). [Online, diakses 5 april]

Notoatmodjo, S. 2010. Metodologi Penelitian Kesehatan. Jakarta : Rineka Cipta.

Potter, Perry. (2010). Fundamental Of Nursing: Consep, Proses and Practice. Edisi 7. Vol. 3. Jakarta: EGC

Sriyono. 2019. Promoting Spiritual Nursing Care in an Intensive Care Unit: A Systematic Review. Indian Journal of Public Health Research \& Development, Volume: 10, Issue: 8.

Triwibowo, C \& Pusphandani, M. E. (2015).Pengantar Dasar Ilmu Kesehatan Masyarakat. Yogyakarta: Nuha Medika

Wawan, D. (2010). Pengetahuan, Sikap dan Perilaku Manusia. Yogyakarta: Nuha Medika.

Yoga, dkk (2019). Pelatihan Reklaksasi dzikir Untuk Menurunkan Stres Santri Rumah Tahfidz "Z". Jurnal Psikologi 2019, 2 (1) , 8-16

Zakiah Daradjat, 1990. Ilmu Jiwa Agama. Jakarta: Bulan Bintang 